\title{
Partial Resistance to Bacterial Wilt in Transgenic Tomato Plants Expressing Antibacterial Lactoferrin Gene
}

\author{
Tae-Jin Lee, Dermot P. Coyne, Thomas E. Clemente, and Amitava Mitra ${ }^{1}$ \\ Department of Agronomy and Horticulture, University of Nebraska, Lincoln, NE 68583
}

ADDITIONAL INDEX WORDS. Lycopersicon esculentum, Ralstonia solanacearum, bacterial concentrations, early resistance, Agrobacterium, Mendelian segregation

\begin{abstract}
Expression of lactoferrin $(L F)$ gene, a cationic iron-binding glycoprotein, was investigated in transgenic tomato plants (Lycopersicon esculentum Mill.). Resistance of the transgenic tomato plants to the pathogen (Ralstonia solanacearum Smith) causing bacterial wilt was also determined. Tomato line F7926-96, susceptible to bacterial wilt, was transformed with Agrobacterium strain C58C1 containing a plasmid construction carrying a modified $L F$ cDNA. The introgression of $L F$ cDNA into the susceptible tomato line was confirmed by Southern blot and the expression of full-length lactoferrin transcript and protein was also detected by northern and western blots, respectively. Based on resistance to kanamycin, a Mendelian segregation for a single locus insertion was observed in the $T_{1}$ and $T_{2}$ generations and all $T_{1}$ and $T_{2}$ plants resistant to kanamycin showed the single corresponding band of $L F$ cDNA in Southern blot analysis. Two transgenic tomato lines inoculated with $1 \times 10^{7}$ and $1 \times 10^{8}$ colony-forming units $(\mathrm{CFU}) / \mathrm{mL}$ with $R$ s isolate $\mathrm{NC251}(\mathrm{K60}$, race 1$)$ exhibited early resistance and subsequent susceptibility, while $44 \%$ to $55 \%$ of plants survived until maturity (fruit ripening) when inoculated with $1 \times 10^{5} \mathrm{CFU} / \mathrm{mL}$ in comparison with the fully susceptible tomato line. The latter resistance to bacterial wilt in transgenic tomatoes with the stable Mendelian segregation patterns for the $L F$ gene suggests a potential new approach to consider for control of bacterial wilt of tomato. The possible value of this gene along with other plant genes to control bacterial pathogens is discussed.
\end{abstract}

Bacterial wilt, caused by Ralstonia solanacearum Yabuuchi et al. (previously Pseudomonas solanacearum Smith and more recently Burkholderia solanacearum Smith), is a serious disease of tomato (Lycopersicon esculentum) and limits production in the tropics and subtropics (Laferriere et al., 1999). Control of this pathogen is difficult because of its broad host range, vast genetic variability, and widespread distribution over locations (Hayward, 1991). Resistance to $R$. solanacearum ( $R s)$ was identified mainly in two small-fruited species, L. pimpinellifolium Jusl. and in L. esculentum var. cerasiforme (Dunal) Alef. (Prior et al., 1994). These species or their progenies were used in breeding cultivated tomatoes resistant to Rs (Chellemi et al., 1994; Gilbert et al., 1974; Henderson and Jenkins, 1972; Prioretal., 1994; Scottetal., 1993; Sathyanarayana and Anand, 1993).

Tomato breeding lines resistant to $R s$ were listed in the Annual Reports of the Asian Vegetable Research and Development Center, Shanhua, Taiwan, during the 1990s, and resistant lines developed in the Philippines were mentioned by Hanson et al. (1996). However, it has been difficult for breeders to develop large fruited, highly resistant tomato cultivars because of the quantitative inheritance pattern of resistance (Acosta et al., 1964; Hanson et al., 1998), number of genes [quantitative trait loci (QTL)] determining resistance (Danesh et al., 1994; Thoquet et al., 1996), the association of small fruit and resistance to Rs (Acosta et al., 1964), the influence of inoculation methods and bacterial concentrations (Mew and Ho, 1976), temperature and photoperiod effects on expression of resis-

Received for publication 22 May 2001. Accepted for publication 12 Nov. 2001. Published as Nebraska Agricultural Research Division journal series paper 13179. Research was conducted under Project 21-074. We acknowledge financial support from Seminis Vegetable Seeds, 37437 State Hwy. 16, Woodland, CA 95695. We also appreciate technical advice and assistance of Anne Vidaver, Patricia Lambrecht, Dan Higgins, Donn Ladd, Chonglie Ma, Dept. of Plant Pathology, Lisa Sutton, Dept. of Agronomy and Horticulture, and Zhanyuan Zhang, Dept. of Agronomy, Univ. of Missouri, Columbia.

${ }^{1}$ Department of Plant Pathology. tance (Krausz and Thurston, 1975), vast strain variation (Kelman and Person, 1961), and aggressiveness of isolates in tomato fields in the tropics (Wang, 1999). The latter four factors have resulted in instability of expression of resistance to $R s$ in the tropics. An alternative approach to classical breeding is development of a transgenic tomato plant with nonplant antibacterial genes using the Agrobacterium-mediated transformation method. Combining classical breeding and transgenic tomato development should also be considered as approaches to enhance resistance.

Lactoferrin (LF) is one of the more promising antibacterial proteins and so was of interest to us to develop a transgenic plant with a gene to enhance resistance to bacterial pathogens. LF contains an active antimicrobial domain lactoferricin (LFcin), and has broad-spectrum antimicrobial properties against both gramnegative and gram-positive bacteria. LF, a cationic iron-binding glycoprotein, is present in milk, tears, saliva, and mucous secretions of most mammals (Masson et al., 1966) and has a major role in the immune system of newborns by modulating immune functions (Fleet, 1995). Recently its three-dimensional structure was determined in mare LF that has a molecular mass of $\approx 80 \mathrm{ku}$ ( $u=$ unified atomic mass unit) (Sharma et al., 1998). Most antimicrobial activities of LF on bacteria are considered as bactericidal, although it was reported that the bactericidal effect of LF on Escherichia coli [(Migula) Castellani and Chalmers] was strain- and dose-dependent and was influenced by the concentration of the bacterial inoculum (Dionysius et al., 1993). The pepsin hydrolysate of LF is bactericidal, whereas LF itself is only bacteriostatic even at high concentrations (Branen and Davidson, 2000; Tomita et al., 1991). In addition, LF has inhibition effects on rotavirus and poliovirus, interfering with an early phase of virus infection in a dose-dependent manner (Marchettiet al., 1999; Superti et al., 1997). The bactericidal abilities of both human and bovine LF are due to specific cationic peptides (peptides I, II, and III) from an antimicrobial domain and the three cationic active peptides created by a pepsin digest of LF are localized in the $\mathrm{N}$-terminus of LF and do not include iron-binding 
sites (Bellamy et al., 1992; Dionysius and Milne, 1997). According to the study of Dionysius and Milne (1997), peptide I is almost identical to bovine LFcin which is a major contributor to the bactericidal effect. Peptides II and III have sequences that previously have not been reported to be antibacterial. Bellamy et al. (1993) demonstrated that the antibacterial sequence matching up to the active peptide is the structural domain responsible for the bactericidal properties of LF. In addition to the antibacterial and antivirus activities, bovine LF showed an immunostimulating activity on the mucosal immune system of mice (Debbabi et al., 1998).

Expression of nonplant antibacterial genes such as $L F$ in a transgenic plant has potential for bacterial disease resistances. Production of LF in tobacco (Nicotiana tabacum L.) cells indicated a potential for development of bacterial disease resistant plants (Mitra and Zhang, 1994). Zhang et al. (1998) then found that the $L F$ gene delayed expression of bacterial wilt symptoms in transgenic tobacco. However, further research is needed to determine if the effects of LF on resistance to bacterial wilt could be confirmed in other plant species. Therefore, the objective of this research was to integrate and express an $L F$ gene into tomato to determine potential resistance to bacterial wilt.

\section{Materials and Methods}

BINARY VECTORS AND Agrobacterium tumefaciens STRAINS. The plasmid pMODC643 containing a modified $L F$ cDNA was the original plasmid used for tobacco transformation (Mitra and Zhang, 1994). This binary vector was mobilized into Agrobacterium tumefaciens strain C58C1 (Koncz and Schell, 1986) by the triparental mating method (Ditta et al., 1980). The integrity of the binary vector in the Agrobacterium strain was confirmed by plasmid rescue.

Plant Material. Tomato line F7926-96 (provided by David M.
Tricoli, Seminis Vegetable Seeds, Woodland, Calif.), susceptible to bacterial wilt, was used for tomato transformation. Mature seeds were surface disinfested by immersion in $1.05 \% \mathrm{NaOCl}$ plus two to three drops of Tween- 20 for $10 \mathrm{~min}$ and rinsed five times with sterile water. The seeds were then germinated in a Magenta box $(3 \times 3 \times 4$ inches, Sigma Co., St. Louis) containing Murashige and Skoog (MS) medium with basal salts (Murashige and Skoog, 1962), Nitsch vitamins (Thomas and Pratt, 1981), 3\% sucrose, and $0.8 \%$ agar at $\mathrm{pH}$ 5.7. The Magenta boxes were then placed in a growth room at $24^{\circ} \mathrm{C}$ under a $16-\mathrm{h}$ photoperiod of $45 \mathrm{mmol} \cdot \mathrm{m}^{-2} \cdot \mathrm{s}^{-1}$ (measured using LI185A quantum light meter, LI-COR Co., Lincoln, Nebr.) at the rim of the boxes provided by cool-white fluorescent lamps for $10 \mathrm{~d}$.

Agrobacterium CULTURING CONDITIONS. Agrobacterium cultures were grown at $27^{\circ} \mathrm{C}$ on yeast extract and peptone (Difco Laboratories, Detroit) medium (peptone at $10 \mathrm{~g} \cdot \mathrm{L}^{-1}$, yeast extract at $5 \mathrm{~g} \cdot \mathrm{L}^{-1}$ and $\mathrm{NaCl}$ at $\left.5 \mathrm{~g} \cdot \mathrm{L}^{-1}, \mathrm{pH} 7.0\right)$ supplemented with the appropriate antibiotics to an optical density (OD, $650 \mathrm{~nm}$ ) of 0.4 to 0.6 . The Agrobacterium was collected by centrifugation at 3,500 $g_{n}$ for 10 min, and the pellet was resuspended to a final OD of 0.4 to 0.6 in a liquid cocultivation medium.

Plant transformation and Regeneration. Tomato transformation and regeneration protocols used herein were described by Fillati et al. (1987) and Meissner et al. (1997) with minor modifications. Middle portions of cotyledons $(\approx 0.5 \mathrm{~cm}$ in length) were used for Agrobacterium-mediated transformation. After cocultivation, explants were transferred to fresh shoot induction medium every 2 weeks for 4 to 6 weeks. When regenerated shoots reached 3 to $4 \mathrm{~cm}$ in height, they were excised and transferred to rooting medium containing MS salts (Murashige and Skoog, 1962), Nitsch vitamins (Thomas and Pratt, 1981), 3\% sucrose, 10 mM indole-3-butyric acid (IBA), kanamycin at $75 \mathrm{mg} \cdot \mathrm{L}^{-1}$, cefotaxime at $100 \mathrm{mg} \cdot \mathrm{L}^{-1}$, carbenicillin at $150 \mathrm{mg} \cdot \mathrm{L}^{-1}$, and $0.8 \%$ agar. After rooting for 1 to 2 weeks,

Table 1. Segregation of kanamycin resistance (NPT II gene) in the $\mathrm{T}_{1}$ and $\mathrm{T}_{2}$ generations of tomato.

\begin{tabular}{|c|c|c|c|c|}
\hline $\mathrm{T}_{0}$ plant & $\begin{array}{l}\text { No. of plants } \\
\text { observed in } T_{1} \\
\quad\left(R^{z}: S\right)\end{array}$ & $\begin{array}{c}\text { No. of plants expected } \\
\text { [Expected ratio }(3: 1)] \\
(\mathrm{R}: \mathrm{S})\end{array}$ & $\chi^{2}$ & $P$ \\
\hline F7926-96 & $0: 40$ & --- & -- & $\begin{array}{l}-- \\
\end{array}$ \\
\hline $\mathrm{LF}^{\mathrm{x}}-\mathrm{T}_{0}-4$ & $18: 7$ & $18.75: 6.25$ & 0.12 & 0.73 \\
\hline $\mathrm{LF}-\mathrm{T}_{0}-11$ & $23: 7$ & $22.5: 7.5$ & 0.04 & 0.83 \\
\hline $\mathrm{LF}^{0} \mathrm{~T}_{0}-17$ & $14: 4$ & $13.5: 4.5$ & 0.07 & 0.79 \\
\hline $\mathrm{LF}^{0} \mathrm{~T}_{0}-18$ & $8: 8$ & $12: 4$ & 5.33 & 0.02 \\
\hline $\mathrm{LF}^{-\mathrm{T}_{0}}-20$ & $20: 8$ & $21: 7$ & 0.19 & 0.66 \\
\hline $\mathrm{LF}^{-\mathrm{T}_{0}}-27$ & $17: 7$ & $18: 6$ & 0.22 & 0.64 \\
\hline $\mathrm{LF}^{-\mathrm{T}_{0}}-28$ & $8: 4$ & $9: 3$ & 0.44 & 0.50 \\
\hline $\mathrm{LF} \mathrm{T}_{0}-29$ & $12: 4$ & $12: 4$ & 0.00 & 1.00 \\
\hline $\mathrm{LF}^{-\mathrm{T}_{0}}-30$ & $12: 3$ & $11.25: 3.75$ & 0.20 & 0.65 \\
\hline $\mathrm{LF}^{-} \mathrm{T}_{0}-34$ & $17: 12$ & $21.75: 7.25$ & 4.15 & 0.04 \\
\hline LF-T $_{0}-102$ & $21: 12$ & $24.75: 8.25$ & 2.27 & 0.13 \\
\hline Total & $170: 76$ & $184.5: 61.5$ & 4.56 & 0.03 \\
\hline
\end{tabular}

Heterogeneity $\chi^{2}=8.47(\mathrm{df}=10), 0.1<P\left(\chi^{2} \geq 8.47\right)<0.9$
$\mathrm{LF}^{-} \mathrm{T}_{1}-11$
$\mathrm{LF}_{1}-20$
$\mathrm{LF}_{1}-29$
$\mathrm{LF}_{\mathrm{T}}-34$
LF-T $_{1}-102$
${ }^{\mathrm{z}}$ Resistant $=\mathrm{R}$ and suceptible $=\mathrm{S}$.
${ }^{\mathrm{y}}$ Nontransgenic tomato line.
${ }^{x} \mathrm{LF}=$ lactoferrin.
${ }^{\mathrm{w}} \mathrm{NA}=$ not applicable.

$\begin{array}{cccc}36: 14 & 37.5: 12.5 & 0.24 & 0.62 \\ 220: 0 & \mathrm{NA}^{\mathrm{w}} & \mathrm{NA} & \mathrm{NA} \\ 60: 22 & 61.5: 20.5 & 0.15 & 0.70 \\ 104: 40 & 108: 36 & 0.59 & 0.44 \\ 99: 38 & 102.75: 34.25 & 0.55 & 0.46\end{array}$


the rooted transgenic plantlets were transferred to a sterile paper pot (6-cm diameter and 0.1 -L volume) containing a sterile medium of 1 soil : 1 peat : 0.5 vermiculite : 0.5 sand (by volume), and then covered by a Magenta container to maintain high humidity around the plants. Transgenic plants were grown in a growth chamber at 24 $\pm 1^{\circ} \mathrm{C}$ with a $16-\mathrm{h}$ photoperiod of $41 \mathrm{mmol} \cdot \mathrm{m}^{-2} \cdot \mathrm{s}^{-1}$ (measured using LI-185A quantum light meter; LI-COR) at the rim of the paper pots from cool-white fluorescent lamps for 1 week, and then transferred to larger clay pots (16-cm diameter and 1.6-L volume) and placed on a greenhouse bench.

SEGREGATION RATIOS OF KANAMYCIN RESISTANCE GENE (NPT II) IN THE $\mathbf{T}_{1}$ AND $\mathbf{T}_{2}$ GENerations. The seeds harvested from fruits of primary transformed plant $\left(\mathrm{T}_{0}\right)$ and self-fertilized plant $\left(\mathrm{T}_{1}\right)$ were germinated on medium containing kanamycin at $150 \mathrm{mg} \cdot \mathrm{L}^{-1}$ for 3 weeks. The tomato seedlings with hairy roots and normal growth were counted as kanamycin resistant plants and those with dark green cotyledons, no hairy roots, and abnormal growth were counted as susceptible plants. Based on the number of resistant and susceptible plants, the expected segregation ratio of resistant and susceptible plants in the $\mathrm{T}_{1}$ and $\mathrm{T}_{2}$ generations was tested using the chisquare $\left(\chi^{2}\right)$ test (Table 1$)$.

ENZYME-LINKED IMMUNOSORBENT ASSAY (ELISA). Transgenic tomato seedlings at the five- to seven-leaf stage were screened using an NPT II ELISA kit (5 Prime--->3 Prime, Boulder, Colo.) to detect $N P T$ II (neomycin phosphotransferase II) protein in plant tissues. The assay procedure and quantitation of NPT II protein were conducted following the manufacturer's instruction. The absorbance was measured at $405 \mathrm{~nm}$ against a blank in a microtiter well reader (Microplate EL309; Bio-Tek Instruments, Frederick, Md.).

SOUTHERN BLOT ANALYSIS. Total genomic DNA was prepared from tomato leaves as described by Dellaporta et al. (1983). Fifteen micrograms of DNA was digested with HindIII restriction enzyme at $37^{\circ} \mathrm{Covernight} \mathrm{and} \mathrm{separated} \mathrm{on} \mathrm{an} \mathrm{agarose} \mathrm{gel}(0.8 \%)$. DNA was transferred to Zeta-Probe nylon membrane (Bio-Rad, Hercules, Calif.) and cross-linked by an ultraviolet crosslinker (Stratalinker UV Crosslinker, Stratagene, La Jolla, Calif.). Gel eluted $L F$ cDNA fragment [2082 base pairs (bp)] was used for the ${ }^{32} \mathrm{P}$-labeled probe. Hybridization was performed overnight at $65^{\circ} \mathrm{C}$ and the membrane washed three times for $30 \mathrm{~min}$ each with washing solutions at $65^{\circ} \mathrm{C}$. The washed membranes were exposed to Kodak X-OMAT film (Eastman Kodak Co., Rochester, N.Y.) in a cassette kept at $-80{ }^{\circ} \mathrm{C}$ for $1 \mathrm{~d}$.

NorThern BLOT ANALYSIS. Young leaf tissues were collected (about $500 \mathrm{mg}$ ) from each tomato seedling and ground in a mortar with liquid nitrogen. For isolation of total RNA, Trizol reagent (Life Technologies, Mol. Res. Ctr., Inc., Grand Island, N.Y.) was used following the manufacturer's instruction. Sixteen micrograms of total RNA was separated on a formaldehyde agarose gel $(1 \%)$ and the gel presoaked in $20 \times$ saline-sodium citrate buffer for $15 \mathrm{~min}$ followed by transfer to a Zeta-Probe GT membrane (Bio-Rad) using a TurboBlotter (Schleicher \& Schuell, Inc., Keene, N.H.). Hybridization was conducted by the same method as described for the Southern blot.

WeStern BLOT ANALYSIS. Young leaves collected from ten to twenty 3-week-old seedlings were used for extraction of total protein following the procedures described by Perez-Garcia et al. (1995). Rabbit antilactoferrin antibody (Zymed Laboratories, Inc., San Francisco), a purified immunoglobulin fraction of rabbit antiserum, was used as the primary antibody $(1: 1000, \mathrm{v} / \mathrm{v})$. The same amounts of total protein $(50 \mathrm{mg})$ from each $\mathrm{T}_{2}$ line were loaded and separated on a 7.5\% Tris-HCl Ready Gel (Bio-Rad). An Amplified Alkaline Phosphatase Goat Anti-Rabbit Immun-Blot Assay Kit
(Bio-Rad) was used for the immun-blot assay following the manufacturer's instructions.

IN VIVO TESTS FOR RESISTANCE OF TOMATO TRANSFORMANTS TO BACTERIAL WILT. In the first experiment a split-plot experimental design was used with two bacterial concentrations of the $R s$ isolate as main plots, and the subplots contained one plant of each of seven $\mathrm{T}_{1}$ tomato lines inoculated with $R s$ and phosphate buffer, respectively, and a susceptible line (check) replicated in each of two growth chambers. In 16-h photoperiod, average irradiances at the rim of pots (139 $\mathrm{cm}$ below the light source) and at the middle level between the rim of pots and the light source $(70 \mathrm{~cm}$ below the light source) in the growth chambers were 122 and $205 \mathrm{mmol} \cdot \mathrm{m}^{-2} \cdot \mathrm{s}^{-1}$ (measured using LI-185A quantum light meter, LI-COR), respectively, provided by 12 cool-white fluorescent lamps. The isolate of $R s$ designated as NC 251 (K60, race 1) (Kelman and Person, 1961) was provided by A. Vidaver, Dept. of Plant Pathology, University of Nebraska, Lincoln, who obtained it from J. Denny, University of Georgia, Athens. A single colony of Rs grown on solid nutrient broth yeast(NBY) (Vidaver, 1967) medium was put into liquid tryptic soy broth (Difco Laboratories, Detroit) medium and then allowed to grow overnight at $28^{\circ} \mathrm{C}$ in a shaker at $200 \mathrm{rpm}$. When the bacterial suspension reached an OD of 0.8 to 1.0 at $640 \mathrm{~nm}$ it was diluted in $0.0125 \mathrm{M}$ phosphate buffer and kept on ice until ready to use. Two different bacterial concentrations $\left[1 \times 10^{7}\right.$ and $1 \times 10^{8}$ colonyforming units $(\mathrm{CFU}) / \mathrm{mL}]$ were used for inoculation of 8 -week-old plants. $\mathrm{T}_{1}$ plants were inoculated once with the sharp end of a no. 20 sewing needle at the lower portion of the main stem with $5 \mathrm{~mL}$ of each bacterial suspension as described by Zhang et al. (1998). Plants used for controls were inoculated with $0.0125 \mathrm{M}$ phosphate buffer. A constant temperature $\left(28 \pm 2{ }^{\circ} \mathrm{C}\right)$ was maintained in the growth chambers. Water was supplied as needed. Plants were observed twice daily to record the date of initiation of plant wilting and the number of plants without wilting symptoms.

In the second experiment, two plants of the susceptible control line F7926-96 and three plants of each of the $\mathrm{T}_{2}$ lines, $\mathrm{LF}_{-} \mathrm{T}_{2}-29$ and $\mathrm{LF}_{-} \mathrm{T}_{2}-34$, were inoculated with a lower concentration of $1 \times 10^{5}$ $\mathrm{CFU} / \mathrm{mL}$ of the $R s$ isolate in each of three growth chambers. The $\mathrm{T}_{2}$ lines were derived from $\mathrm{T}_{1}$ plants that showed the best early resistance to $R s$ under the high bacterial concentrations in the first experiment. A randomized complete block design with three replications was used. Eight-week-old plants were inoculated as described previously. All other conditions, procedures, and data recording were similar to those used in the first experiment except that a lower temperature regime of $26 \pm 2$ and $21 \pm 2{ }^{\circ} \mathrm{C}$ during the 16 and $8 \mathrm{~h}$ light and dark periods, respectively, was used.

REISOLATION OF Rs FROM THE INOCULATED PLANTS. For confirmation of the causal bacterial pathogen of the disease, the bacterium was isolated from the control plants and $\mathrm{T}_{1}$ transgenic plants $10 \mathrm{~d}$ after inoculation. Young stems or fully developed leaves were collected from the upper parts of both wilted plants and resistant plants. The bacterium was then isolated from plant sap in the tissues using a sterile needle. The bacteria were grown on solid NBY medium in plates, replicated twice, at $28^{\circ} \mathrm{C}$ in the dark for $4 \mathrm{~d}$. The 4-d-old cultures were used to prepare bacterial suspensions. Susceptible F7926-96 tomato plants were inoculated with the bacterial suspension $\left(1 \times 10^{7} \mathrm{CFU} / \mathrm{mL}\right)$ to determine if typical bacterial wilt symptoms would occur.

\section{Results}

Plant transformation and Regeneration of Transformed PLANTS. The plasmid vector containing an $L F$ gene and a selectable 
marker (NPT II) gene was transformed into the bacterial wilt susceptible line F7926-96 by the Agrobacterium-mediated transformation method. Over $70 \%$ of transformed calli or shoots were obtained from the explants on the selection medium containing kanamycin at $150 \mathrm{mg} \cdot \mathrm{L}^{-1}$. Most of the early regenerated shoots did not form roots and died in the rooting medium containing kanamycin at $75 \mathrm{mg} \cdot \mathrm{L}^{-1}$. However, about $80 \%$ of the regenerated calli survived on the selection medium and produced shoots that formed roots on the rooting medium. The rooted shoots grew into tomato plantlets that were transferred later to the greenhouse. Ten to $20 \%$ of the tomato plantlets did not survive during the acclimatization period in the greenhouse. The survivors grew normally to maturity and set fruit, except that some $\mathrm{T}_{0}$ plants set no fruit or only small seedless fruit.

Molecular analysis of Primary Transformants. After the acclimatization period, the transformed tomato plants were screened initially by the NPT II ELISA test to identify putative $\mathrm{T}_{0}$ plants. About $87 \%$ of the putative $\mathrm{T}_{0}$ plants (34 out of 39 plants analyzed) showed positive responses for the NPT II ELISA test. Seven $\mathrm{T}_{0}$ tomato lines were used to quantify the level of NPT II protein in total protein (Fig. 1). Seven transformed tomato lines and a transgenic tobacco plant that contained the NPT II gene had a relatively high level of NPT II protein in comparison to a nontransformed tomato line F7926-96. Ten $\mathrm{T}_{0}$ tomato plants out of 34 plants that showed positive response to NPT II ELISA test were further analyzed by Southern blot to confirm introgression of $L F$ cDNA into the plant genome. HindIII-digested genomic DNA from 10 primary transformants showed $2.4 \mathrm{~kb}$ bands that corresponded to the full length of $L F$ cDNA (Fig. 2). Two additional larger bands from two transgenic tomato lines ( $\mathrm{LF}_{-} \mathrm{T}_{0}-11$ and $\mathrm{LF}_{-} \mathrm{T}_{0}-34$ ) could be explained by either an incomplete digestion of the genomic DNA with the restriction enzyme or in vivo alteration of the restriction site, most likely because of the rearrangements of the integrated gene.

Segregation of NPTII Gene IN $\mathbf{T}_{1}$ AND $\mathrm{T}_{2}$ Generations. Segregation data of kanamycin resistance and susceptibility in the $\mathrm{T}_{1}$ and $\mathrm{T}_{2}$ generations are shown in Table 1. Although the number of plants was limited because of the harvest of small numbers of seeds from the primary transformants, nine out of $11 \mathrm{~T}_{1}$ tomato lines showed a good fit to a $3: 1$ ratio of kanamycin resistant and susceptible plants, indicating the presence of the NPT II gene for resistance in the progeny. A chi-square test was conducted to determine if there was heterogeneity among the progenies (Table 1). The calculated chisquare value supports the presence of overall homogeneity among families. Also, the segregation of resistance and susceptibility was tested on $\mathrm{T}_{2}$ seeds derived from five $\mathrm{T}_{1}$ tomato lines that produced a large number of seeds. Four $\mathrm{T}_{1}$ tomato lines showed a good fit to a 3:1 ratio of resistant to susceptible plants in the $T_{2}$ generation supporting the hypothesis of a single locus insertion for the NPT II gene. But one $\mathrm{T}_{1}$ tomato line, $\mathrm{LF}_{-} \mathrm{T}_{1}-20$, did not show any segregation in the $\mathrm{T}_{2}$ generation suggesting that $\mathrm{LF}-\mathrm{T}_{1}-20$ was homozygous for the NPT II gene insertion.

REACTION OF TRANSGENIC TOMATO PLANTS TO BACTERIAL WILT. In the first experiment, $T_{1}$ tomato plants were inoculated with two concentrations of $R s$ to evaluate bacterial resistance in growth chambers. A total of 48 tomato plants, including $42 \mathrm{~T}_{1}$ plants from seven different lines and six nontransgenic plants F7926-96 (control), were used for inoculation (Table 2). When all leaves of the inoculated plant were fully wilted, the plant was regarded as $100 \%$ wilted. The nontransgenic control plants inoculated with $1 \times 10^{7}$ and $1 \times 10^{8} \mathrm{CFU} / \mathrm{mL}$ started to wilt 7 and $5 \mathrm{~d}$ after inoculation, respectively, and were totally wilted 11 and $10 \mathrm{~d}$ after inoculation, respectively. No wilting occurred in nontransgenic and transgenic plants inoculated with phosphate buffer. In two of the transgenic lines, $\mathrm{LF}-\mathrm{T}_{1}-29$ and $\mathrm{LF}-\mathrm{T}_{1}-34$ inoculated with $1 \times 10^{7}$ and $1 \times 10^{8}$ $\mathrm{CFU} / \mathrm{mL}$, wilting was significantly delayed, occurring at 23 and 24 $\mathrm{d}$, respectively, in comparison to $10 \mathrm{~d}$ for control plants. $\mathrm{LF}-\mathrm{T}_{1}-34$ inoculated with $1 \times 10^{7} \mathrm{CFU} / \mathrm{mL}$ wilted $16 \mathrm{~d}$ later than the control plants, whereas wilting was delayed by only $4 \mathrm{~d}$ in two transgenic lines, $\mathrm{LF}-\mathrm{T}_{1}-11$ and $\mathrm{LF}-\mathrm{T}_{1}-28$, inoculated with both concentrations. The overall delay of wilting of seven transgenic lines differed from the control plants, although the delay in wilting varied among individual transgenic plants and lines. There was a significant difference in wilting resulting from two inoculum concentrations, with the higher concentration causing more severe and quicker wilting symptoms than the lower concentration of inoculum. The control plants did not show any significant difference between the two inoculum concentrations, whereas one transgenic line, $\mathrm{LF}-\mathrm{T}_{1}$ 102 , responded very differently to both inoculum concentrations.

In the second experiment both $\mathrm{T}_{2}$ lines inoculated with $1 \times 10^{5}$ $\mathrm{CFU} / \mathrm{mL}$ showed high survival rates of $44 \%$ and $55 \%$ (four and five out of nine plants, respectively) up to early fruit ripening $56 \mathrm{~d}$ after inoculation, at which time the experiment was terminated (Fig. 3). All plants of the susceptible line F7926-96 were dead $26 \mathrm{~d}$ after inoculation. These results are in marked contrast to the first experiment where all plants of both $\mathrm{T}_{1}$ lines $\mathrm{LF}-\mathrm{T}_{1}-29$ and $\mathrm{LF}-\mathrm{T}_{1}-34$ were

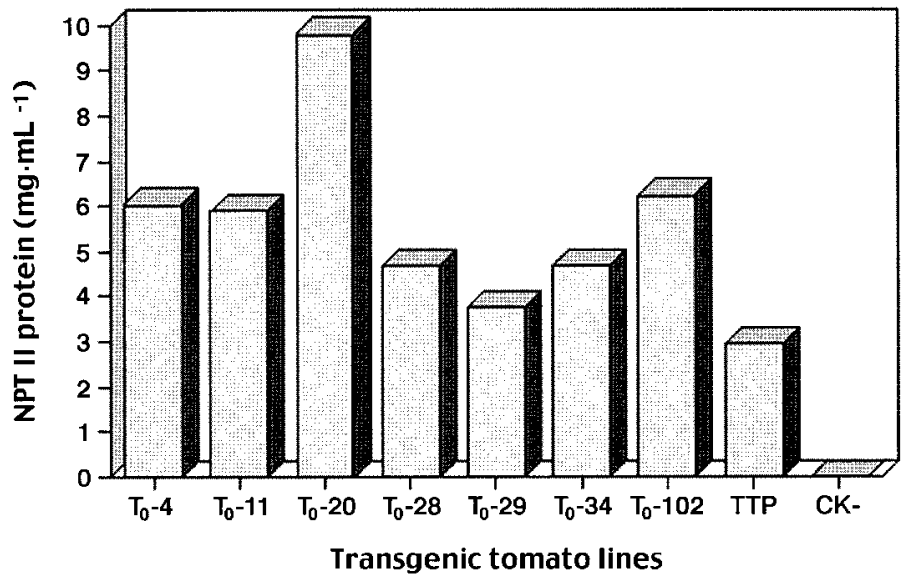

Fig. 1. Levels of NPT II protein in $\mathrm{T}_{0}$ tomato seedlings determined by ELISA with absorbance at $405 \mathrm{~nm}$. Bars 1-7 from left to right, transgenic tomato lines $\left(\mathrm{T}_{0}\right)$; TTP, transgenic tobacco plant as a positive control; CK-, nontransgenic tomato line F7926-96 as a negative control.

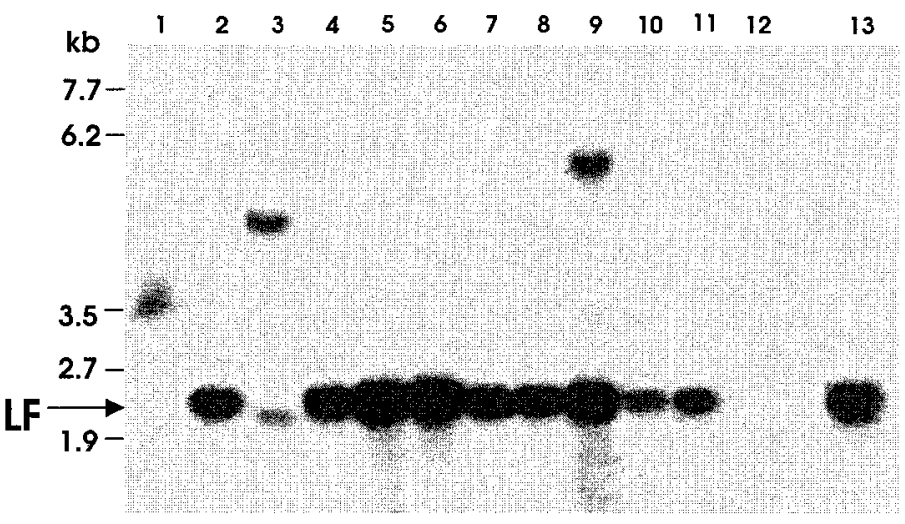

Fig. 2. Southern analysis of HindIII-digested genomic DNA extracted from primary tomato transformants $\left(\mathrm{T}_{0}\right)$. Lane 1 ; marker, lanes 2-11; primary transformants containing lactoferrin $\mathrm{DNA}$ (from left to right, $\mathrm{LF}-\mathrm{T}_{0^{-}}-7, \mathrm{LF}-\mathrm{T}_{0^{-}}$ $11, \mathrm{LF}-\mathrm{T}_{0}-20, \mathrm{LF}-\mathrm{T}_{0}-26, \mathrm{LF}-\mathrm{T}_{0}-27, \mathrm{LF}-\mathrm{T}_{0}-28, \mathrm{LF}-\mathrm{T}_{0}-29, \mathrm{LF}-\mathrm{T}_{0}-30, \mathrm{LF}-\mathrm{T}_{0^{-}}$ 34, and $\mathrm{LF}-\mathrm{T}_{0}-102$ ) and lane 12; nontransgenic tomato line F7926-96, and lane 13; plasmid DNA of lactoferrin. 
Table 2. Mean number of days to complete wilting of nontransgenic and transgenic tomato $\left(\mathrm{T}_{1}\right)$ plants inoculated with phosphate $\left(\mathrm{PO}_{4}\right)$ buffer and two inoculum concentrations, $1 \times 10^{7}$ and $1 \times 10^{8} \mathrm{CFU} / \mathrm{mL}$, of $R$ s under a 16 -h photoperiod at constant temperature $\left(28 \pm 2{ }^{\circ} \mathrm{C}\right)$ in growth chambers.

\begin{tabular}{|c|c|c|c|c|c|}
\hline \multirow[b]{2}{*}{$\begin{array}{l}\text { Tomato } \\
\text { line }\end{array}$} & \multicolumn{3}{|c|}{$\mathrm{MDAI}^{\mathrm{z}}$} & \multirow[b]{2}{*}{$\begin{array}{c}\text { Differences } \\
\text { between } \mathrm{A} \text { and } \mathrm{B}^{\mathrm{y}}\end{array}$} & \multirow[b]{2}{*}{$\begin{array}{c}\text { Means of } \\
\text { A and B }\end{array}$} \\
\hline & $\begin{array}{l}\mathrm{PO}_{4} \\
\text { buffer }\end{array}$ & $\underset{\left(1 \times 10^{7} \mathrm{CFU} / \mathrm{mL}\right)}{\mathrm{A}}$ & $\begin{array}{c}\text { B } \\
\left(1 \times 10^{8} \mathrm{CFU} / \mathrm{mL}\right)\end{array}$ & & \\
\hline F7926-96 & $\mathrm{NW}^{\mathrm{w}}$ & 11 & 10 & 1 & 10 \\
\hline $\mathrm{LF} \mathrm{T}_{1}-11$ & NW & 16 & 12 & 5 & 14 \\
\hline $\mathrm{LF} \mathrm{T}_{1}-20$ & NW & 18 & 15 & 3 & 17 \\
\hline $\mathrm{LF}^{-\mathrm{T}_{1}}-27$ & NW & 18 & 17 & 1 & 17 \\
\hline $\mathrm{LF} \mathrm{T}_{1}-28$ & NW & 15 & 13 & 2 & 14 \\
\hline $\mathrm{LF}^{-\mathrm{T}_{1}}-29$ & NW & 25 & 21 & 4 & 23 \\
\hline $\mathrm{LF}-\mathrm{T}_{1}-34$ & NW & 27 & 22 & 5 & 24 \\
\hline $\mathrm{LF} \mathrm{T}_{1}-102$ & NW & 20 & 12 & 9 & 16 \\
\hline Line mean ${ }^{v}$ & & 20 & 16 & 4 & 18 \\
\hline $\operatorname{LSD}_{(0.05)}$ & & 3 & 2 & 3 & 2 \\
\hline
\end{tabular}

${ }^{\mathrm{z}} \mathrm{MDAI}=$ mean number of days for complete wilting of plants (two plants per line) after inoculation.

${ }^{y}$ Differences in number of days for wilting of plants due to two inoculum concentrations, A and B.

${ }^{x}$ Nontransgenic tomato line susceptible to bacterial wilt.

${ }^{\mathrm{w}} \mathrm{NW}=$ no wilt

${ }^{\mathrm{v}}$ Means of seven transgenic lines.

dead 23 to $24 \mathrm{~d}$ after inoculation.

REISOLATION OF Rs FROM THE INOCULATED PLANTS. The isolated bacterial colonies from the control plants in the first experiment showed morphologically identical characteristics in comparison to those of a pure culture of $R s$. No colonies of $R s$ were detected on the plates from the $\mathrm{LF}-\mathrm{T}_{1}-34$ line.

EXPRESSION OF $\boldsymbol{L F}$ GENE IN TRANSGENIC TOMATO PLANTS. The young stems from the upper parts of the inoculated $T_{1}$ plants in the first experiment that showed delayed wilting for more than $7 \mathrm{~d}$ were rescued by vegetative propagation 2 weeks after inoculation. The vegetatively propagated stems grew into healthy plants, flowered, and set tomato fruit that produced normal mature $\mathrm{T}_{2}$ seeds. These $\mathrm{T}_{2}$ seeds were used for northern and western blots to detect expression

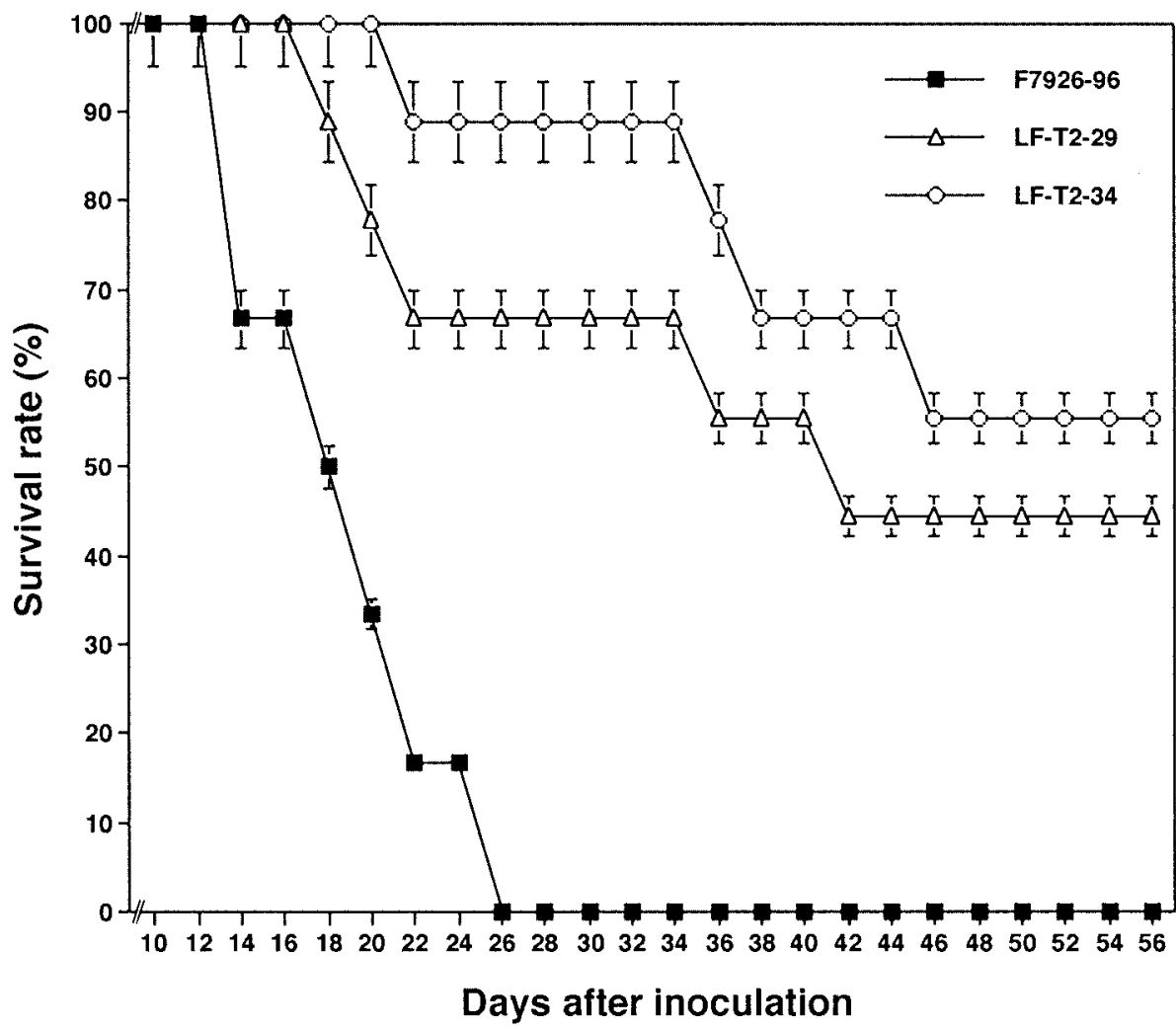

of $L F$ gene in the $\mathrm{T}_{2}$ generation. The $\mathrm{T}_{2}$ seeds were screened on germination medium containing kanamycin at $150 \mathrm{mg} \cdot \mathrm{L}^{-1}$ and the kanamycin resistant seedlings were used in northern and western blots.

For analysis of $L F$ gene expression in the $\mathrm{T}_{2}$ generation, total RNA and protein were extracted from $\mathrm{T}_{2}$ tomato plants that showed different and relatively high levels of early resistance to $R s$ in the first inoculation experiment. Northern and western blots were performed with total RNA and protein samples (Figs. 4 and 5). Northern blot results revealed that two $\mathrm{T}_{2}$ tomato lines, $\mathrm{LF}_{-} \mathrm{T}_{2}-29$ and $\mathrm{LF}_{-} \mathrm{T}_{2}-34$, showed high levels of $2.3-\mathrm{kb}$ transcripts in all five plants from each line, although there were differences in the levels of 2.3-kb transcripts among the plants. In addition to northern blot results, western blot results showed that two $\mathrm{T}_{2}$ tomato lines, $\mathrm{LF}_{-} \mathrm{T}_{2}-29$ and $\mathrm{LF}_{-} \mathrm{T}_{2}-34$, had high LF protein levels based on the intensities of LF protein bands, and two other $\mathrm{T}_{2}$ tomato lines, $\mathrm{LF}_{-} \mathrm{T}_{2}-20$ and $\mathrm{LF}_{2} \mathrm{~T}_{2}-102$, showed relatively low levels of LF. These results agreed with the results of the first inoculation experiment. Also, the approximate size of these bands $(80 \mathrm{ku})$ was the same as the full-length LF protein reported earlier (Chong and Langridge, 2000; Mitra and Zhang, 1994; Zhang et al., 1998).

\section{Discussion}

Introgression of $L F$ cDNA into a tomato line susceptible to $R s$ using Agrobacteriummediated transformation method was demonstrated. A Mendelian segregation pattern for a single locus insertion of the NPT II gene was observed in the $T_{1}$ and $T_{2}$ generations and all

Fig. 3. Percentage survival of plants of two $T_{2}$ transgenic tomato lines (LF- $\mathrm{T}_{2}-29$ and $\left.\mathrm{LF} \mathrm{T}_{2}-34\right)$ and susceptible check (F7926-96) for days after inoculation with $1 \times 10^{5}$ $\mathrm{CFU} / \mathrm{mL}$ of $R s$ under a $16-\mathrm{h}$ photoperiod at $26 \pm 2$ and 21 $\pm 2{ }^{\circ} \mathrm{C}$ during the 16 and $8 \mathrm{~h}$ light and dark periods, respectively. Vertical bars indicate SES ( $n=6$ in F792696 and $n=9$ in each $T_{2}$ transgenic tomato line). 


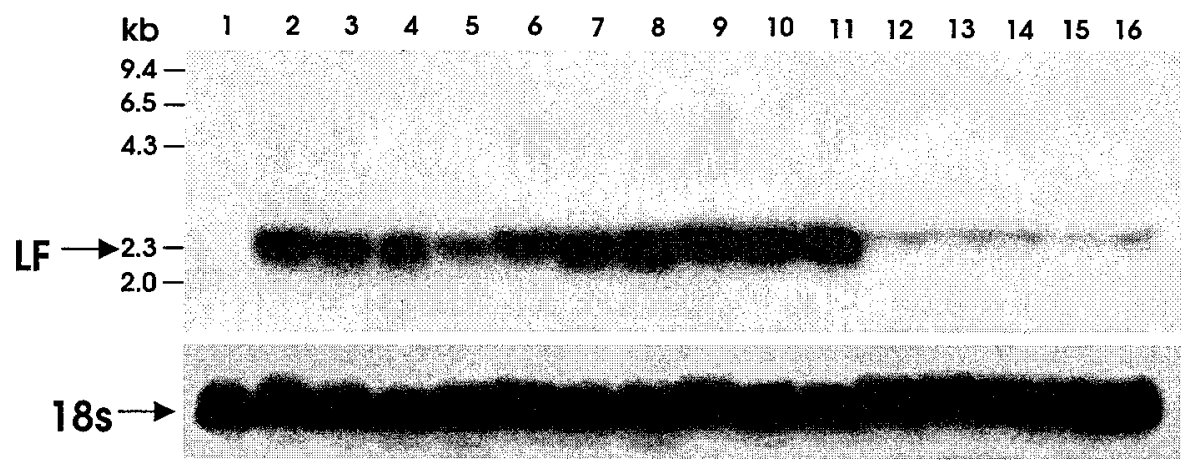

tomato lines were associated with levels of resistance to $R S$ in the transgenic tomato lines. Mitra and Zhang (1994) first reported on expression of $L F$ gene in transgenic tobacco calli providing a high level of antibacterial activity against four different bacterial pathogens, although all of the tobacco calli produced only truncated 48-ku LF protein. A major band showing full-length $\mathrm{LF}$ protein $(\approx 80 \mathrm{ku})$ occurred in transgenic tobacco plants as well as the truncated LF protein only in several transgenic tobacco plants that showed higher levels of resistance to $R s$. An association of disease

Fig. 4. Northern analysis of lactoferrin mRNA from $\mathrm{T}_{2}$ transgenic tomato plants that germinated on medium containing kanamycin at $150 \mathrm{mg} \cdot \mathrm{L}^{-1}$. Lane 1 ; negative control mRNA from a nontransgenic tomato line F7926-96, lanes 2-6; mRNA from progenies of $\mathrm{LF}_{-} \mathrm{T}_{2}-29$ line, lanes $7-11$; mRNA from progenies of $\mathrm{LF}-\mathrm{T}_{2}-34$ line, and lanes 12-16; mRNA from progenies of $\mathrm{LF}-\mathrm{T}_{2}-20$ line. The same blot was hybridized with a lactoferrin DNA probe (upper) and an 18s DNA probe (lower) as an internal control.

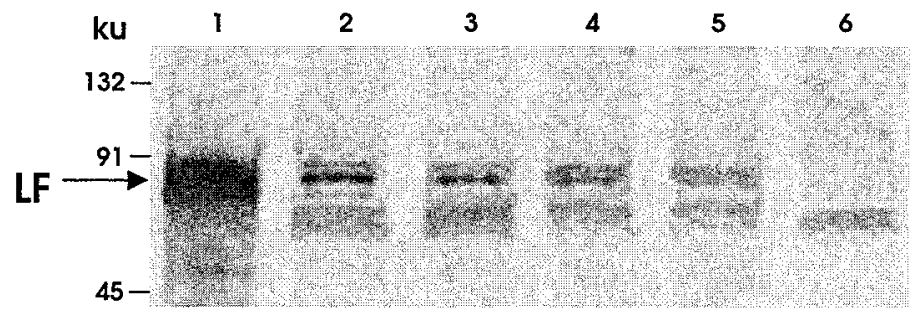

Fig. 5. Assay for lactoferrin protein isolated from tomato leaf samples $(\mathrm{u}=$ unified atomic mass unit). Lane 1; nontransformed tomato F7926-96 + lactoferrin protein (10 ng), lanes 2-5; $\mathrm{T}_{2}$ transgenic tomato lines $\mathrm{LF}-\mathrm{T}_{2}-29, \mathrm{LF}-\mathrm{T}_{2}-34, \mathrm{LF}-$ $\mathrm{T}_{2}-20$, and $\mathrm{LF}-\mathrm{T}_{2}-102$, respectively, and lane 6; nontransgenic tomato line F7926-96.

$\mathrm{T}_{1}$ and $\mathrm{T}_{2}$ tomato plants resistant to kanamycin exhibited the single corresponding band to $L F$ cDNA in Southern blot analysis. These results confirmed that both linked NPT II and $L F$ genes showed stable and Mendelian cosegregation in the $\mathrm{T}_{1}$ and $\mathrm{T}_{2}$ generations.

$L F$ appears to be one of the promising nonplant antibacterial genes with potential for control of aggressive bacterial pathogens such as Rs. Dionysius and Milne (1997) suggested that two different antibacterial mechanisms might exist within LF. One is bacteriostatic activity related closely to iron chelation through two ironbinding sites and the other is bactericidal activity limited to an active and exposed peptide LFcin. Zhang et al. (1998) demonstrated that bovine LFcin was more bactericidal than shiva-1, which is one of the widely used non-plant synthetic antimicrobial peptides, at concentrations of $10 \mathrm{~mm}$ or more against three bacterial pathogens. They suggested that the strong bactericidal effects of bovine LFcin were caused by the smaller and more cationic peptides of bovine LFcin than those of shiva-1, which permitted easier access to the bacterial membrane. Therefore, these properties of LF could contribute to the higher antibacterial activities to bacterial pathogens than other nonplant genes.

In this study expression of $L F$ gene in the $\mathrm{T}_{1}$ transgenic tomato plants resulted in only expression of early resistance to $R s$ in the presence of high bacterial concentrations $\left(1 \times 10^{7}\right.$ and $1 \times 10^{8} \mathrm{CFU} /$ $\mathrm{mL})$. However, $44 \%$ to $55 \%$ of the $\mathrm{T}_{2}$ plants maintained resistance to the fruit ripening stage when inoculated with the lower $1 \times 10^{5}$ $\mathrm{CFU} / \mathrm{mL}$ concentration. The latter experiment was terminated at that time. Western blot analysis revealed production of only fulllength LF protein (about $80 \mathrm{ku}$ ) in the transgenic tomato plants. The variable translational levels of the $L F$ gene in different transgenic resistance with LF levels was noted (Zhang et al., 1998). Our work in tomato confirms further earlier observations in tobacco. Chong and Langridge (2000) recently demonstrated that only full-length LF protein was produced in transformed potato (Solanum tuberosum L.) tuber tissues and that the antibacterial activity against four human pathogenic bacterial species was stronger in tuber extracts which contained more LF protein. The relation of the antibacterial effects of the truncated peptides of LF in transgenic tobacco calli and plants to the level of resistance to bacterial pathogens is still unclear.

Koziel et al. (1993) speculated that some variations of the level of toxin expression in $B t$-transgenic plants might depend on the plant species. Also, the response of inoculated chitinase transgenic plants to fungal pathogens depends on the plant species (Punja and Raharjo, 1996). Since the transgenic tobacco plants showed higher levels of resistance to $R s$ than transgenic tomato plants, it is also possible that there may be plant species-dependent mechanisms for posttranscription or posttranslation modulation of the LF transcript or protein in transgenic plants and that those mechanisms could affect the level of resistance to the bacteria. The different bacterial concentrations in the inoculation experiment may contribute to variations in resistance levels between the transgenic tobacco and tomato plants. Mew and Ho (1976) demonstrated that several tomato cultivars shifted from resistant to moderately resistant or moderately susceptible to $R s$ when the inoculum concentration was increased from $10^{6}$ to $10^{7}$ or $10^{8} \mathrm{CFU} / \mathrm{mL}$. Zhang et al. (1998) used $R s$ suspension of $2.5 \times 10^{6} \mathrm{CFU} / \mathrm{mL}$ for inoculation of $\mathrm{T}_{1}$ tobacco plants while concentrations of $1 \times 10^{7}$ and $1 \times 10^{8}$, and $1 \times 10^{5} \mathrm{CFU} /$ $\mathrm{mL}$ were used by us in the first and second experiments, respectively. Early resistance was only expressed in tomatoes under the higher bacterial concentrations while a high survival rate to maturity of $\mathrm{T}_{2}$ plants was detected with the lower bacterial concentration. It is also possible that some variations in the site and placement of the inocula in the stem inoculations could have contributed to the variable responses of the inoculated plants because the bacterium grows in and moves through the xylem of the plant.

Stem inoculation using a high bacterial concentration is regarded as a more severe test than the commonly used inoculation tests in the greenhouse and in the field. Although we were not in a position to conduct field tests with these $T_{1}$ and $T_{2}$ plants, it is suggested based on the severe inoculation tests in growth chambers that the plants might express higher levels of resistance in the field. Breeders have noted instability of expression of resistance determined by plant genes. It is also possible that these more resistant transformed tomato lines might express more stable resistance in the presence of a wide array of aggressive $R s$ isolates in the field (Wang, 1994). We think that $R s$ strain specificity to LF is unlikely as LF was found to inhibit growth of a number of different pathogenic bacterial genera and species in vitro (Mitra and Zhang, 1994).

Tomato breeders have found it difficult in the past to break the 
linkage of small fruit size and resistance to $R s$ (Acosta et al., 1964). Although some undesirable transformed variants are expected they are likely to be less of a problem than unfavorable tight linkages of plant genes. Fruit on our transformed tomato plants appeared normal. Hanson et al. (1998) reported that improvement in resistance to $R s$ was not obtained by combining different sources of resistant germplasm. It would be useful to determine if enhanced and more stable resistance could be obtained by combining plant genes for resistance now in elite germplasm with the gene for LF. If successful, this could provide a new approach for better management of $R s$.

\section{Literature Cited}

Acosta, J.C., J.C. Gilbert, and V.L. Quinon. 1964. Heritability of bacterial wilt resistance in tomato. Proc. Amer. Soc. Hort. Sci. 84:455-462.

Bellamy, W.R., M. Takase, K. Yamauchi, H. Wakabayashi, K. Kawase, and M. Tomita. 1992. Identification of the bactericidal domain of lactoferrin. Biochim. Biophys. Acta 1121:130-136.

Bellamy, W.R., H. Wakabayashi, M.Takase, K. Kawase, S. Shimamura, and M. Tomita. 1993. Role of cell-binding in the antibacterial mechanism of lactoferrin B. J. Appl. Bacteriol. 75:478-484.

Branen, J. and P.M. Davidson. 2000. Activity of hydrolysed lactoferrin against foodborne pathogenic bacteria in growth media: The effect of EDTA. Lett. Appl. Microbiol. 30: 233-237.

Chellemi, D.O., H.A. Dankers, S.M. Olson, N.C. Hodge, and J.W. Scott. 1994. Evaluating bacterial wilt-resistant tomato genotypes using a regional approach. J. Amer. Soc. Hort. Sci. 119:325-329.

Chong, D.K.X. and W.H.R. Langridge. 2000. Expression of full-length bioactive antimicrobial human lactoferrin in potato plants. Transgenic Res. 9:71-78.

Danesh, D., S. Aarons, G.E. McGill, and N.D. Young. 1994. Genetic dissection of oligogenic resistance to bacterial wilt in tomato. Mol. Plant-Microbe Interact. 7:464-471.

Debbabi, H., M. Dubarry, M. Rautureau, andD. Tome. 1998. Bovine lactoferrin induces both mucodal and systemic immune response in mice. J. Dairy Res. 65:283-293.

Dellaporta, S.L., J. Wood, and J.B. Hicks. 1983. A plant DNA minipreparation: Version II. Plant Mol. Biol. Rptr. 1:19-21.

Dionysius, D.A., P.A. Grieve, and J.M. Milne. 1993. Forms of lactoferrin: Their antibacterial effect on enterotoxigenic Escherichia coli. J. Dairy Sci. 76:2597-2606.

Dionysius, D.A. and J.M. Milne. 1997. Antibacterial peptides of bovine lactoferrin: Purification and characterization. J. Dairy Sci. 80:667-674.

Ditta, G., S. Stanfield, D. Corbin, and D.R. Helinski. 1980. Broad host range DNA cloning system for gram-negative bacteria: Construction of a gene bank of Rhizobium meliloti. Proc. Natl. Acad. Sci. USA 77:7347-7351.

Fillati, J.J., J. Kiser, R. Rose, and L. Comai. 1987. Efficient transfer of a glyphosate tolerance gene into tomato using a binary Agrobacterium tumefaciens vector. Biotechnology 5:726-730.

Fleet, J.C. 1995. A new role for lactoferrin: DNA binding and transcription activation. Nutri. Rev. 53:226-231.

Gilbert, J.C., J.S. Tanaka, and K.Y. Takeda. 1974. 'Kewalo' tomato. HortScience 9:481-482.

Hanson, P.M., O. Licardo, Hanudin, J.F., Wang, and J.T. Chen. 1998. Diallel analysis of bacterial wilt resistance in tomato derived from different sources. Plant Dis. 82:74-78.

Hanson,P.M.,J.F.Wang, O.Licardo,Hanudin, S.Y.,Mah, G.L.Hartman, Y.C.Lin, and J.T. Chen. 1996. Variable reaction of tomato lines to bacterial wilt evaluated at several locations in southeast Asia. HortScience 31:143-146.

Hayward, A.C. 1991. Biology and epidemiology of bacterial wilt caused by Pseudomonas solanacearum. Annu. Rev. Phytopathol. 29:65-87.

Henderson, W.R. and S.F. Jenkins, Jr. 1972. 'Venus' and 'Saturn' tomato varieties resistant to southern bacterial wilt. HortScience 7:346.

Kelman, A. and L.H. Person. 1961. Strains of Pseudomonas solanacearum differing in pathogenicity to tobacco and peanut. Phytopathology 51:158 161.
Koncz, C. and J. Schell. 1986. The promoter of TL-DNA gene 5 controls the tissue-specific expression of chimeric genes carried by a novel type of Agrobacterium binary vector. Mol. Gen. Genet. 204:383-396.

Koziel, M.G., G.L. Beland, C. Bowman, N.B. Carozzi, R. Crenshaw, L. Crossland, J. Dawson, N. Desai, M. Hill, S. Kadwell, K. Launis, K. Lewis, D. Maddox, K. McPherson, M.R. Meghji, E. Merlin, R. Rhodes, G.W. Warren, M. Wright, and S.V. Evola. 1993. Field performance of elite transgenic maize plants expressing an insecticidal protein derived from Bacillus thuringiensis. Biotechnology 11:194-200.

Krausz, J.P. and H.D. Thurston. 1975. Breakdown of resistance to Pseudomonas solanacearum in tomato. Phytopathology 65:1272-1274.

Laferriere, L.T., J.P.Helgeson, and C. Allen. 1999. Fertile Solanum tuberosum $+S$. commersonii somatic hybrids as sources of resistance to bacterial wilt caused by Ralstonia solanacearum. Theor. Appl. Genet. 98:1272-1278.

Marchetti, M., F. Superti, M.G. Ammendolia, P. Rossi, P. Valenti, and L. Seganti. 1999. Inhibition of poliovirus type 1 infection by iron-, manganeseand zinc-saturated lactoferrin. Med. Microbiol. Immunol. 187:199-204.

Masson, P.L., J.F. Heremans, and C. Dive. 1966. An iron-binding protein common to many external secretions. Clinic Chim. Acta 14:735.

Meissner, R., Y. Jacobson, S. Melamed, S. Levyatuv, G. Shalev, A. Ashri, Y. Elkind, and A. Levy. 1997. A new model system for tomato genetics. The Plant J. 12:1465-1472.

Mew, T.W. and W.C. Ho. 1976. Varietal resistance to bacterial wilt in tomato. Plant Dis. Rptr. 60:264-268.

Mitra, A. and Z. Zhang. 1994. Expression of a human lactoferrin cDNA in tobacco cells produces antibacterial proteins. Plant Physiol. 106:977-981.

Murashige, T. and F. Skoog. 1962. A revised medium for rapid growth and bioassays with tobacco tissue cultures. Physiol. Plant 15:473-497.

Perez-Garcia, A., F.M. Canovas, F. Gallardo, B. Hirel, and A. de Vincente. 1995. Differential expression of glutamine synthetase isoforms in tomato detached leaflets infected with Pseudomonas syringae pv. tomato. Mol. Plant-Microbe Interactions 8:96-103.

Prior, P., V. Grimult, and J. Schmit. 1994. Resistance to bacterial wilt (Pseudomonas solanacearum) in tomato: Present status and prospects, $\mathrm{p}$. 209-223. In: A.C. Hayward and G.L. Hartman (eds.). Bacterial wilt: The disease and its causative agent Pseudomonas solanacearum. CAB Intl., Wallingford, United Kingdom.

Punja, Z.K. and S.H.T. Raharjo. 1996. Response of transgenic cucumber and carrot plants expressing different chitinase enzymes to inoculation with fungal pathogens. Plant Dis. 8:999-1005.

Sathyanarayana, H.V. and N. Anand. 1993. Developing bacterial wilt resistant $\mathrm{F}_{1}$ hybrids for processing in tomato (Lycopersicon esculentum). Austral. Centre Intl. Agr. Res. Proc. 45:158-162.

Scott, J.M., G.C. Somodi, and J.B. Jones. 1993. Testing tomato genotypes and breeding for resistance to bacterial wilt in Florida. Austral. Centre Intl. Agr. Res. Proc. 45:126-131.

Sharma, A.K., M. Paramasivam, A. Srinivasan, M.P. Yadav, and TejP. Singh. 1998. Three-dimensional structure of mare diferric lactoferrin at $2.6 \AA$ resolution. J. Mol. Biol. 289:303-317.

Superti, F., G. Ammendolia, P. Valenti, and L. Seganti. 1997. Antirotaviral activity of milk proteins: Lactoferrin prevents rotavirus infection in the enterocyte-like cell line HT-29. Med. Microbiol. Immunol. 186:83-91.

Thomas, B.R. and D. Pratt. 1981. Efficient hybridization between Lycopersicon esculentum and L. peruvanum via embryo callus. Theor. Appl. Genet. 59:215-219.

Thoquet, P., J. Oliver, C. Sperisen, P. Rogowsky, H. Laterrot, and N. Grimsley. 1996. Quantitative trait loci determining resistance to bacterial wilt in the tomato cultivar Hawaii. 1996. Mol. Plant-Microbe Interact. 9:826-836.

Tomita, M., W. Bellamy, M. Takase, K. Yamauchi, H. Wakabayashi, and K. Kawase. 1991. Potent antibacterial peptides generated by pepsin digestion of bovine lactoferrin. J. Dairy Sci. 74:4137-4142.

Wang, J.F. 1999. Variation in genotype and aggressiveness of Ralstonia solanacearum in tomato fields. Annu. Rpt. Asian Veg. Res. Dev. Ctr. p. 7-9.

Zhang, Z., D.P. Coyne, A.K. Vidaver, and A. Mitra. 1998. Expression of human lactoferrin cDNA confers resistance to Ralstonia solanacearum in transgenic tobacco plants. Phytopathology 88:730-734. 